\title{
Faunistic Characterization of Alpine springs in the Swiss National Park
}

\author{
Stefanie von Fumetti \& Susanne Felder
}

Keywords: Alpine springs, Swiss National Park, macroinvertebrates, endangered species

\section{Abstract}

Springs are unique habitats for highly adapted organisms that are endangered by anthropogenic impacts. The springs in the Swiss National Park (SNP) have remained largely free of direct anthropogenic impacts since the foundation of the park. Monitoring of these unaffected Alpine springs is therefore of special interest. In this project 19 springs in the SNP and the adjacent Val Müstair Biosphere Reserve were investigated. In early summer and autumn 2012, the springs were mapped and physiochemical parameters were measured. The macroinvertebrates were sampled quantitatively with a surber sampler and qualitatively by hand-picking. Results show that Diptera, Trichoptera and Plecoptera are the most diverse orders. Within these orders, cold-stenothermal species with alpine altitudinal preferences and endemic species were found. They are partly endangered or at least vulnerable in Switzerland. The macroinvertebrate species assemblages of the springs show a high degree of individuality. However, looking at the species assemblages, springs at different sites or valleys differ significantly from each other. This underlines the importance of protected areas as sanctuaries for threatened species living in endangered habitats such as springs. Moreover, a protection of the springs outside of the SNP would be desirable.
Profile

Protected area

Swiss National Park \& Val Müstair

Biosphere Reserve

Mountain range

Alps

Country

\section{Switzerland}

\section{Introduction}

Springs are multiple ecotones between the groundwater and the surface water and provide a habitat for specialized organisms (Cantonati et al. 2006). Perennial springs exhibit reduced variability of environmental conditions (van der Kamp 1995; Cantonati et al. 2012). Alpine springs are even more special as species have to adapt to lower temperatures and a short growth season during summer. Environmental changes and anthropogenic impacts have severely endangered these springs. In the Swiss Jura mountains and in the Central Plateau, few springs remain in a natural condition (Zollhöfer 1997). Alpine springs are also threatened, for instance, by cattle grazing and trampling (Wigger \& von Fumetti 2013). They are sensitive habitats, usually of a small spatial extent (Cantonati \& Ortler 1998) and fed by small catchment areas (Cantonati et al. 2006). Recent studies on Alpine springs in Switzerland were conducted e.g. by Weber 2004, Robinson et al. 2008 and Wigger \& von Fumetti 2013.

Springs in protected Alpine areas have been intensively monitored in Berchtesgaden National Park in Germany (Gerecke \& Franz 2006), where over 330 springs have been investigated. In Austria, the Kalkalpen and Gesäuse National Parks were intensively monitored in the past ten years (e.g. Weigand 1998; Weigand \& Graf 2004; Gerecke et al. 2012). In the Swiss National Park (SNP) research is one of the main aims, therefore the fauna and flora is well investigated. However, scientific research on springs in the SNP has been mostly limited to chemical and physi-

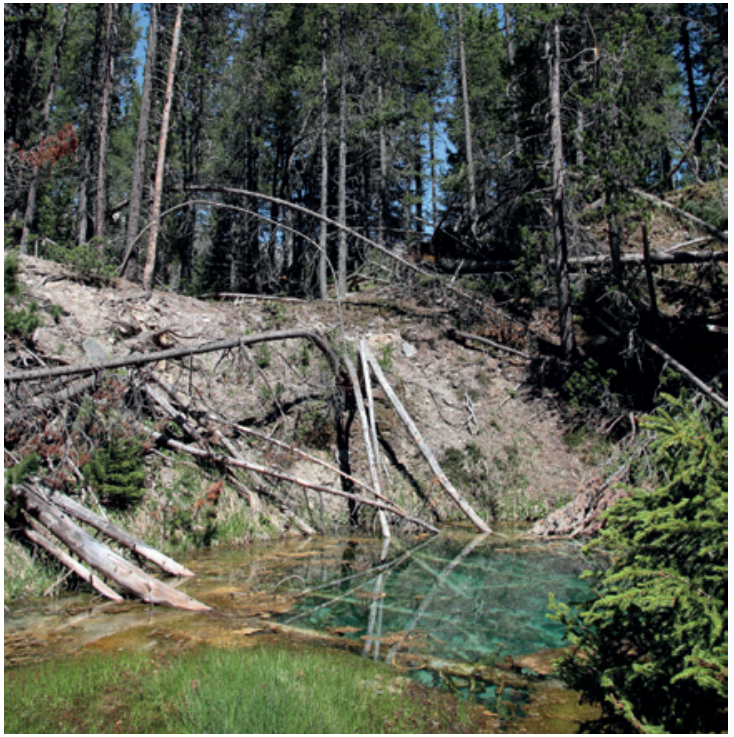

Figure 1 - A typical spring in the Swiss National Park. (C) S. Felder

cal parameters (Nold \& Schmassmann 1955; Döring 2002) and to certain taxa, such as water mites (Bader 1975) and stoneflies (Aubert 1965). There is one study from Nadig (1942), who closely investigated five springs around Il Fuorn. With its long-standing protection since 1914, the SNP is still a very remote and natural area with over 200 natural springs recorded in the areas Val dal Spöl, Il Fuorn and the valleys around Il Fuorn (Steiner 2005).

In this study, 19 springs were investigated of which 14 are situated within the borders of the SNP and five 


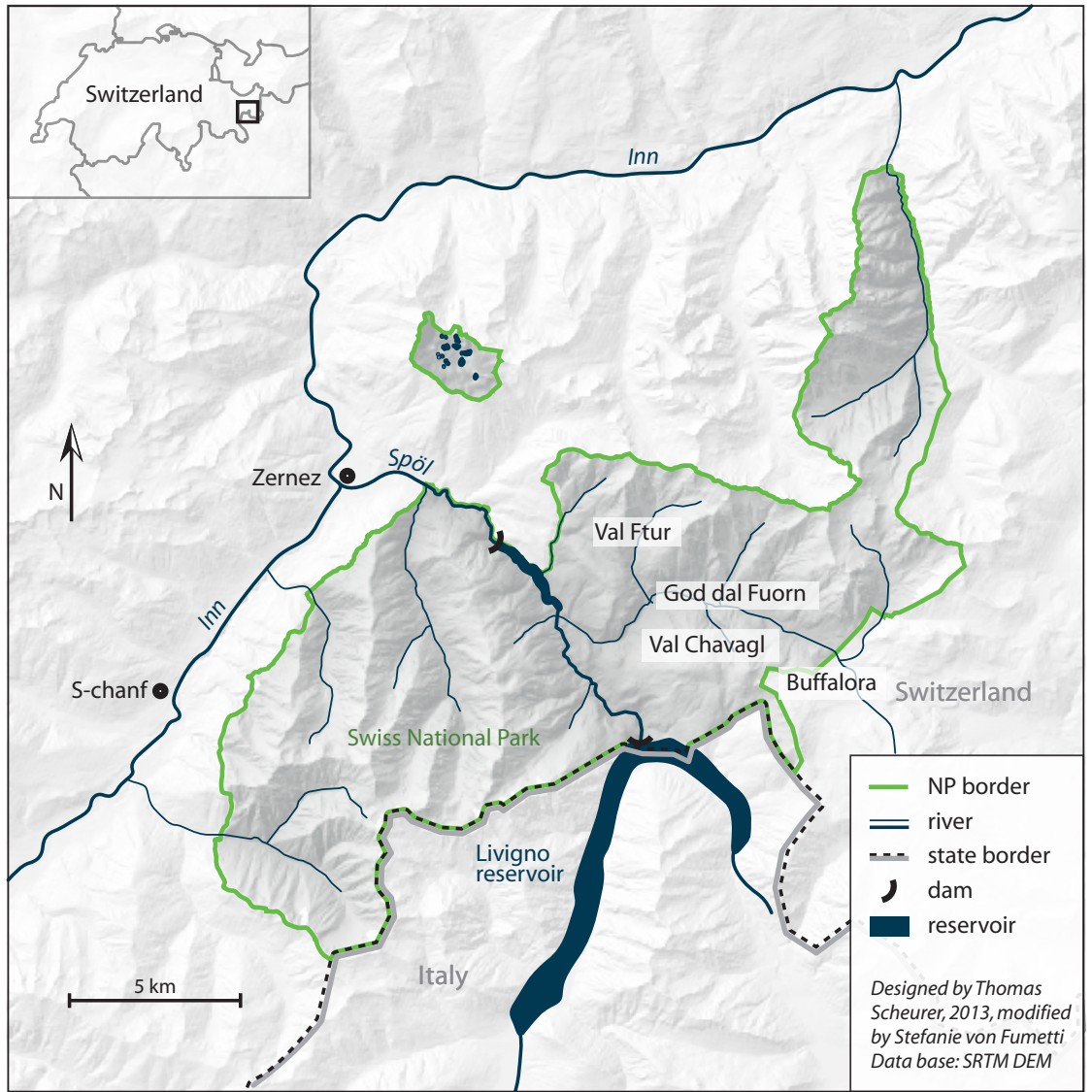

Figure 2 - Locations of the springs within the SNP in the side valleys $\mathrm{Val}$ Ftur and $\mathrm{Val}$ Chavagl and around God dal Fuorn. Five springs are located in the region Buffalora in Val Müstair BR.

in the area of Buffalora in Val Müstair Biosphere Reserve (BR). The aims of the study were (a) to determine the main abiotic factors influencing the macroinvertebrate assemblages of the springs within and outside the SNP and (b) to assess the function of the SNP as a sanctuary for endangered species. This study gives a first comprehensive insight into the fauna of the springs around Il Fuorn in the SNP and the Alp Buffalora in Val Müstair BR.

\section{Methods}

\section{Study site}

The SNP was founded in 1914 and has been subject to total nature protection since then. Fourteen of the investigated springs are situated within the SNP around the hotel Il Fuorn in the side valleys Val Ftur and Val Chavagl and around God dal Fuorn. Five springs are located in the region Buffalora in Val Müstair BR (Table 1 \& Figure 2). All springs are geologically located in the Engadine Dolomites (Trümpy 1997). The altitudinal range of the springs varies from $1770 \mathrm{~m}$ to $2255 \mathrm{~m}$. This alpine to subalpine area is covered by snow for up to nine months a year. The mean precipitation at Buffalora is $793 \mathrm{~mm} / \mathrm{a}(1968 \mathrm{~m}$; MeteoSchweiz 2013). The average annual air temperature reaches $0.7{ }^{\circ} \mathrm{C}$; temperatures vary between $-9.2^{\circ} \mathrm{C}$ during winter and $10.3^{\circ} \mathrm{C}$ during summer. Increasing temperatures have been measured since 1990 (Ketterer \& Haller 2009). The studied springs all flow into the Ova dal Fuorn that feeds the river Spöl. Most investigated springs are rheocrenes. The springs Q4, GF1 and BUF5 were characterized as helocrenes and BUF1, FiW and LIM as limnocrenes. The springs in the Buffalora region in Val Müstair BR are moderately influenced by extensive cattle grazing. Despite the total nature protection, few springs within the park are used for drinking water supply.

\section{Faunistic and abiotic sampling}

All springs were sampled twice, in early June and late September 2012. Of each spring four quantitative samples were taken with a small surber sampler $(10 \mathrm{~cm} \times 10 \mathrm{~cm} ; 500 \mu \mathrm{m}$ mesh) after von Fumetti et al. (2006). Additionally the springs were sampled by hand-picking. All samples were preserved in $80 \%$ ethanol and sorted afterwards in the laboratory. Specimens were identified to species level whenever possible. Demanding taxa, such as Chironomids were identified to sub-family level or grouped into morphospecies. Water temperature, $\mathrm{pH}$, oxygen content and saturation, and electrical conductivity were measured using portable meters (WTW, Weilheim, Germany). The discharge was measured using a plastic bag and a graduated cylinder after Zollhöfer et al. (2000). The springs were mapped geomorphologically based on the manual by Lubini et al. (2009).

\section{Statistical analysis}

All statistical analyses were calculated using PRIMER 6.0 (Clarke \& Gorley 2006). The statistical analysis of the faunistic data was performed with the data 
of the quantitative sampling. For the faunistic data, the Bray-Curtis similarity and a fourth root-transformation were used. Abiotic data were normalized and the Euclidian distance was used as similarity measure. Ordination of the springs was conducted using nonmetric multidimensional scaling (nMDS). The analysis of similarities procedure (ANOSIM), which is analogous to an ANOVA but relies on a similarity matrix and makes few assumptions about the data, was used for testing the grouping of the springs. Additionally a principal components analysis (PCA) and a BESTanalysis (Biota and Environmental Matching) were performed. In the BEST analysis, the Spearman rank correlation is used for correlating faunistic and abiotic data. The combination of abiotic variables with the highest $\varrho$ value best describes the faunistic distribution ( $\varrho$ between 1 and -1 ).

\section{Results}

The water temperature in the springs varied from $3.0{ }^{\circ} \mathrm{C}$ (BUF3) to $7.0{ }^{\circ} \mathrm{C}$ (LIM) during the summer sampling (mean: $5.1^{\circ} \mathrm{C}$ ). The temperature amplitude was between 0.1 (GF3, LIM) and 4.7 (BUF4). The $\mathrm{pH}$ ranged from $7.2(\mathrm{Q} 2)$ to $8.9(\mathrm{VCh} 2)$ and the electrical conductivity from $107 \mu \mathrm{S} / \mathrm{cm}$ (BUF3) to 575 $\mu \mathrm{S} / \mathrm{cm}$ (GF1). The limnocrene LIM had a very high electrical conductivity $(1511 \mu \mathrm{S} / \mathrm{cm})$. The oxygen concentration varied from $4.6 \mathrm{mg} / \mathrm{l}$ (GF2) to 10.0 $\mathrm{mg} / \mathrm{l}(\mathrm{OFb} 2)$ and the saturation from $47 \%$ to $98 \%$. The limnocrene LIM had very low values, with an oxygen concentration of $0.3 \mathrm{mg} / 1$ (3\%). Discharge varied from $2 \mathrm{~L} / \mathrm{min}$ (Buf2) to $144 \mathrm{~L} / \mathrm{min}$ in VCh3 (Table 1). Several springs had a much lower discharge in autumn (VCH2, GF1-GF3, BUF1), and the spring BUF5 did not show any surface flow in autumn.

In the springs a total of 63 species and higher taxa were recorded. The number of taxa in any spring was between 4 (BUF3) and 24 (BUF2). Fifty percent of the taxa only occurred in one or two springs, one third of the taxa only occurred in one single spring. The most diverse order were Diptera (19 taxa), Trichoptera (17 taxa), and Plecoptera (12 taxa) (Table 3). Among the Trichoptera and Plecoptera, 15 of 26 species are listed on the Swiss Red List (Lubini et al. 2012). The stonefly Nemoura undulata, a highly isolated species threatened with extinction, was found in the spring at the highest location within the study area on the Alp Buffalora, BUF3. Acrophylax zerberus, a near-endemic species (Oertli et al. 2008), Drusus melanchaetes, Drusus nigrescens and Rhyacophila bonaparti are vulnerable Trichoptera. Also the molluscs Quickella arenaria and Vertigo genesii show a restricted distribution.

For the PCA conducted with the abiotic data, the limnocrene LIM was excluded because of its extremely different physico-chemistry. The PC axes one and two of the PCA explained $35 \%$ and $21 \%$ of the variance, respectively. The first three $\mathrm{PC}$ axes together explained $71 \%$ of the variance. Component one is
Table 1 - Site description

\begin{tabular}{|c|c|c|c|c|}
\hline Site & Area & Altitude [m] & Swiss coordinates & Spring type \\
\hline Q1 & \multirow[t]{5}{*}{ Val Ftur } & 1832 & $811^{\prime} 545 / 171^{\prime} 995$ & Rheocrene \\
\hline Q2 & & 1920 & $810^{\prime} 945 / 172^{\prime} 490$ & Rheocrene \\
\hline Q3 & & 1960 & $810^{\prime} 875 / 172 \prime 555$ & Rheocrene \\
\hline Q4 & & 1900 & $810^{\prime} 740 / 172^{\prime} 600$ & Helocrene \\
\hline Q5 & & 1780 & $811^{\prime} 720 / 171^{\prime} 870$ & Rheocrene \\
\hline Q6 & \multirow[t]{3}{*}{ Val Chavagl } & 1975 & $813^{\prime} 160 / 170^{\prime} 910$ & Rheocrene \\
\hline Q7 & & 1965 & $813^{\prime} 100 / 170^{\prime} 920$ & Rheocrene \\
\hline Q8 & & 1845 & $812^{\prime} 575 / 171^{\prime} 605$ & Rheocrene \\
\hline GF1 & \multirow[t]{5}{*}{ God dal Fuorn } & 1800 & $811^{\prime} 875 / 171^{\prime} 680$ & Helocrene \\
\hline GF2 & & 1802 & $811^{\prime \prime 725 / 171 ' 645}$ & Rheocrene \\
\hline GF3 & & 1805 & $811^{\prime} 760 / 171^{\prime} 620$ & Rheocrene \\
\hline Lim & & 1822 & $812^{\prime} 185 / 171^{\prime} 675$ & Limnocrene \\
\hline FiW & & 1770 & $811^{\prime} 630 / 171^{\prime} 845$ & Limnocrene \\
\hline Buf1 & \multirow[t]{6}{*}{ Buffalora } & 2177 & $816^{\prime} 280 / 168^{\prime} 880$ & Limnocrene \\
\hline Buf2 & & 2176 & $816^{\prime} 260 / 168^{\prime} 830$ & Rheocrene \\
\hline Buf3 & & 2255 & $815^{\prime} 560 / 169^{\prime} 100$ & Rheocrene \\
\hline Buf4 & & 2163 & $816^{\prime} 365 / 169^{\prime} 025$ & Rheocrene \\
\hline Buf5 & & 1980 & $816^{\prime} 360 / 169^{\prime} 900$ & Helocrene \\
\hline OFb2 & & 1960 & $816^{\prime} 120 / 170^{\prime} 560$ & Rheocrene \\
\hline
\end{tabular}

Table 2 - Abiotic characteristics of the investigated springs. Electrical conductivity and oxygen content and saturation are given as means of two measurements. ${ }^{*}$ the physico-chemistry of Buf5 was monitored once; the $p H$ is therefore a single measurement

\begin{tabular}{|c|c|c|c|c|c|c|c|}
\hline Site & \begin{tabular}{|l|} 
pH \\
[median] \\
\end{tabular} & $\begin{array}{l}\text { conductivity } \\
{\left[\mu \mathrm{S} / \mathrm{cm} ; 25^{\circ} \mathrm{C}\right]}\end{array}$ & $\begin{array}{l}\mathrm{O}_{2} \\
{[\mathrm{mg} / \mathrm{I}]}\end{array}$ & $\begin{array}{l}\mathrm{O}_{2} \\
{[\%]}\end{array}$ & $\begin{array}{l}\text { discharge } \\
{[1 / \mathrm{min}]}\end{array}$ & $\begin{array}{l}\text { temperature } \\
{\left[{ }^{\circ} \mathrm{C} \text {; summer }\right]}\end{array}$ & $\begin{array}{l}\text { temperature } \\
{\left[{ }^{\circ} \mathrm{C} \text {; autumn] }\right.}\end{array}$ \\
\hline Q1 & 7.9 & 273 & 8.1 & 96 & 9.6 & 5.0 & 5.3 \\
\hline Q2 & 7.4 & 328 & 7.5 & 93 & 3.6 & 5.7 & 6.7 \\
\hline Q3 & 7.8 & 286 & 8.1 & 96 & 6.0 & 4.5 & 4.8 \\
\hline Q4 & 8.2 & 275 & 7.7 & 93 & 9.6 & 5.2 & 5.4 \\
\hline Q5 & 8.0 & 275 & 9.6 & 95 & 36.0 & 5.2 & 5.7 \\
\hline Q6 & 8.3 & 240 & 9.5 & 93 & 24.0 & 3.0 & 4.8 \\
\hline Q7 & 8.5 & 266 & 8.9 & 87 & 9.6 & 4.0 & 4.7 \\
\hline Q8 & 8.1 & 276 & 9.6 & 94 & 144.0 & 3.0 & 5.2 \\
\hline GF1 & 8.3 & 575 & 6.6 & 68 & 3.6 & 5.2 & 7.0 \\
\hline GF2 & 8.2 & 324 & 4.6 & 47 & 4.2 & 3.8 & 6.5 \\
\hline GF3 & 8.0 & 226 & 8.0 & 79 & 4.2 & 5.9 & 6.0 \\
\hline Lim & 7.5 & 1511 & 0.3 & 3 & 16.8 & 7.0 & 6.9 \\
\hline FiW & 7.6 & 319 & 6.9 & 84 & 3.6 & 4.4 & 6.7 \\
\hline Buf1 & 7.6 & 161 & 7.7 & 79 & 14.4 & 4.9 & 5.2 \\
\hline Buf2 & 7.7 & 213 & 8.4 & 91 & 1.8 & 4.4 & 7.4 \\
\hline Buf3 & 8.3 & 107 & 9.5 & 93 & 16.8 & 2.8 & 3.0 \\
\hline Buf4 & 7.9 & 259 & 6.8 & 73 & 5.4 & 2.7 & 7.4 \\
\hline Buf5 & $7.9^{*}$ & - & - & - & 6.0 & 4.4 & - \\
\hline OFb2 & 8.1 & 185 & 10.0 & 98 & 78.0 & 4.4 & 4.6 \\
\hline
\end{tabular}

dominated by the oxygen concentration (eigenvector $=0.505)$ on the positive axis and by the electrical conductivity (eigenvector $=-0.517$ ) on the negative axis. GF1 and GF2 show a high load on the negative axis of PC1. Component two is dominated by the altitude (eigenvector $=0.611$ ) on the positive axis separating BUF1-BUF4 from the other springs and by the $\mathrm{pH}$ (eigenvector $=-0.408$ ) and the discharge (eigenvector $=-0.408)$ on the negative axis.

In the nMDS analysis, the springs in the different areas were plotted together. Only the springs of the 
Table 3 - List of presence (+) and absence (-) of the 63 taxa at each investigated site.

\begin{tabular}{|c|c|c|c|c|c|c|c|c|c|c|c|c|c|c|c|c|c|c|c|}
\hline & \begin{tabular}{|l|l} 
Q1 & \\
\end{tabular} & \begin{tabular}{|l|l} 
Q2 \\
\end{tabular} & \begin{tabular}{|l|l|} 
Q3 \\
\end{tabular} & Q4 & Q5 & Q6 & Q7 & \begin{tabular}{|l|l} 
Q8 & \\
\end{tabular} & GF1 & \begin{tabular}{|l|l} 
GF2 & C \\
\end{tabular} & \begin{tabular}{|l|l} 
GF3 & L \\
\end{tabular} & LIM & FiW & BUF1 & BUF2 & BUF3 & BUF4 & BUF5 & OFb2 \\
\hline \multicolumn{20}{|l|}{ Turbellaria } \\
\hline Crenobia alpina (Dana, 1766) & + & + & + & + & + & + & + & + & + & + & + & - & + & + & + & + & + & + & + \\
\hline Oligochaeta & - & + & + & + & - & + & + & + & + & + & + & + & + & + & + & - & + & + & + \\
\hline Gastropoda & & & & & & & & & & & & & & & & & & - & \\
\hline Galba truncatula (Müller, 1774) & - & + & - & - & - & - & - & - & + & + & - & + & + & - & + & - & + & + & - \\
\hline Quickella cf. arenaria (Bouchard-Chanteraux, 1837) & - & - & - & - & - & - & - & - & - & - & - & - & - & -1 & - & - & - & + & \\
\hline Columella cf. edentula (Draparnaud, 1805) & - & + & - & - & - & - & - & - & - & - & + & - & - & - & - & - & - & - & - \\
\hline Vertigo genesii (Gredler, 1856) & - & + & - & - & - & - & - & - & - & - & - & - & - & - & - & - & - & - & - \\
\hline Bivalvia & & & & & & & & & & & & & & & & & & - & \\
\hline Pisidum cf. personatum (Malm, 1855) & - & - & - & - & - & - & - & - & - & + & + & + & + & + & - & - & + & + & - \\
\hline Acari & - & - & + & + & - & + & - & - & - & + & - & - & + & + & + & - & + & + & + \\
\hline Ostracoda & - & - & - & + & - & - & - & - & + & + & + & - & + & + & + & - & + & - & - \\
\hline Ephemeroptera & & & & & & & & & & & & & & & & & & - & \\
\hline Baetis alpinus (Pictet, 1843) & + & - & - & - & - & - & - & + & - & - & + & - & - & + & & - & - & - & + \\
\hline Rhithrogena loyolaea (Navas, 1922) & - & + & - & - & + & - & - & + & - & - & - & - & + & - & - & - & - & - & - \\
\hline Plecoptera & & & & & & & & & & & & & & & & & & - & \\
\hline Leuctra armata (Kempny, 1899) & - & - & + & - & - & - & - & - & - & - & - & - & - & - & - & - & - & - & + \\
\hline Leuctra gr. braueri-muranyii & - & + & - & - & - & - & - & - & + & - & - & - & - & - & - & - & - & + & \\
\hline Leuctra cf. rosinae (Kempny, 1900) & - & - & - & - & + & - & + & + & - & - & - & - & - & - & - & + & - & - & - \\
\hline Amphinemura sp. & - & - & - & - & - & - & - & - & - & - & - & - & - & + & - & - & - & - & - \\
\hline Nemoura cinerea (Retzius, 1783) & - & - & - & - & - & - & - & - & + & - & - & - & - & - & - & - & - & - & \\
\hline Nemoura mortoni (Ris, 1902) & - & - & - & + & - & - & - & - & - & - & - & - & - & + & + & - & + & + & + \\
\hline Nemoura cf. sinuata (Ris, 1902) & - & + & - & - & - & - & - & - & - & - & - & - & - & - & + & - & - & - & - \\
\hline Nemoura undulata (Ris, 1902) & - & - & - & - & - & - & - & - & - & - & - & - & - & - & - & + & - & - & - \\
\hline Nemurella pictetii (Klapalek, 1900) & + & - & - & - & - & - & - & - & + & + & + & - & + & + & + & - & + & + & - \\
\hline Protonemura cf. lateralis (Ris, 1902) & + & - & - & + & + & - & + & + & - & - & - & - & + & + & + & - & - & - & + \\
\hline Dictyogenus alpinum (Pictet, 1841) & - & + & + & - & + & - & - & - & - & - & - & - & - & - & + & - & - & - & - \\
\hline Isoperla rivulorum (Pictet, 1841) & - & - & - & - & + & - & - & + & - & - & - & - & + & - & + & - & - & - & + \\
\hline Coleoptera & & & & & & & & & & & & & & & & & & - & \\
\hline Agabus bipustulatus (Linnaeus, 1767) & - & - & - & - & - & - & - & - & - & - & - & - & + & - & - & - & - & - & - \\
\hline Hydroporus sp. & - & - & + & + & - & - & - & - & - & - & - & - & - & - & - & - & - & - & - \\
\hline Haliplus lineatocollis (Marsham, 1802) & - & - & - & - & - & - & - & - & - & - & - & - & + & - & - & - & - & - & - \\
\hline Limnebius sp. & - & - & - & - & - & - & - & - & - & - & - & - & - & - & + & - & - & - & - \\
\hline \multicolumn{20}{|l|}{ Trichoptera } \\
\hline Beraea pullata (Curtis, 1834) & - & - & - & - & - & - & - & - & - & + & + & - & - & - & - & - & - & - & - \\
\hline Lithax niger (Hage, 1859) & - & + & + & - & - & - & - & - & - & - & - & - & + & + & - & - & - & - & + \\
\hline Acrophylax zerberus (Braver, 1867) & - & - & - & - & - & - & + & - & - & - & - & - & - & - & - & - & - & - & - \\
\hline Chaetopterygini/Stenophylacini & - & - & + & + & - & - & + & - & - & - & + & - & - & - & + & - & - & - & + \\
\hline Consorophylax consors (McLachlan 1880) & - & - & + & - & - & - & - & - & - & - & - & - & - & - & - & - & - & - & - \\
\hline Drusus biguttatus (Stephens, 1837) & + & - & - & - & + & - & - & - & - & - & - & - & - & - & - & - & - & - & - \\
\hline Drusus chrysotus (Rambur, 1842) & - & + & - & - & - & - & - & - & - & - & - & - & - & - & - & - & - & - & - \\
\hline Drusus discolor (Rambur, 1842) & - & - & - & - & + & - & - & - & - & - & - & - & - & - & - & - & - & - & - \\
\hline Drusus melanchaetes (McLachlan, 1876) & - & - & - & - & - & - & - & - & - & - & - & - & - & - & - & - & - & - & + \\
\hline Drusus monticola (McLachlan, 1876) & + & - & - & - & + & - & - & + & - & - & - & - & - & - & - & - & - & - & - \\
\hline Drusus nigrescens (Meyer-Dür, 1875) & - & + & - & - & - & - & - & - & - & - & - & - & - & - & - & - & - & - & - \\
\hline Limnephilus coenosus (Curtis, 1834) & - & - & - & - & - & - & - & - & - & - & - & - & - & - & - & - & + & - & - \\
\hline Parachiana picicornis (Pictet, 1834) & - & - & - & - & - & - & - & - & + & - & - & - & - & + & - & - & - & - & - \\
\hline Plectrocnemia conspersa (McLachlan, 18 & - & - & - & - & - & - & - & - & - & - & + & - & - & - & - & - & - & - & - \\
\hline Rhyacophila bonaparti (Schmid, 1947) & - & - & - & + & - & - & - & - & - & - & - & - & - & - & - & - & - & - & - \\
\hline Rhyacophila glareosa (McLachlan, 1867) & - & - & + & + & - & - & - & - & - & - & - & - & + & - & - & - & - & - & - \\
\hline Rhyacophila sensu stricto & + & - & - & - & + & - & - & - & - & - & - & - & - & - & - & - & - & - & - \\
\hline Diptera & & & & & & & & & & & & & & & & & & & \\
\hline Ceratopogoninae & - & + & - & + & - & - & - & - & + & + & - & + & + & + & + & - & + & - & + \\
\hline Chironomidae & + & + & + & + & + & + & + & + & + & + & + & + & + & + & + & + & + & + & + \\
\hline Prodiamesa olivaceae (Meigen, 1818) & - & - & - & - & - & - & - & - & - & + & - & + & + & + & - & - & + & - & - \\
\hline Tanypodinae & - & - & + & + & + & - & - & - & - & + & + & - & + & - & + & - & + & - & 4 \\
\hline Chironomini & $\begin{array}{llll}- & \\
\end{array}$ & - & - & + & - & - & - & - & + & + & + & + & - & + & - & - & + & - & - \\
\hline Tanytarsini & + & + & + & + & - & + & + & - & + & + & + & + & + & + & + & - & + & - & + \\
\hline Culcididae & $\begin{array}{llll}- & & & \end{array}$ & - & - & - & - & - & - & - & - & - & - & + & - & - & - & - & - & - & - \\
\hline Dixa sp. & - & - & + & - & - & - & - & - & - & - & - & - & - & - & - & - & - & - & - \\
\hline Diptera (cont.) & & & & & & & & & & & & & & & & & & & \\
\hline Dolichopodidae & - & - & - & - & - & - & - & - & - & - & - & - & - & - & - & - & + & - & - \\
\hline Clinocerinae & - & - & + & - & + & - & - & + & - & - & - & - & - & - & + & - & - & - & - \\
\hline Limoniinae & + & - & - & - & - & - & - & - & - & - & - & - & - & - & - & - & - & - & - \\
\hline Dicranota sp. & $\begin{array}{llll}- & \\
\end{array}$ & - & + & + & - & - & + & + & - & + & - & - & - & + & + & - & - & - & - \\
\hline Eleophila sp. & + & - & - & - & - & - & - & - & + & - & + & - & + & + & + & - & - & - & - \\
\hline Psychodidae & $\begin{array}{llll}- & \\
\end{array}$ & - & + & + & - & - & - & - & - & + & - & - & - & - & + & - & + & - & - \\
\hline Oxycera cf. pard & + & - & + & - & - & - & - & - & + & - & - & - & - & - & + & - & - & - & - \\
\hline Oxycera cf. pseudoamoena (Dusek \& Rozkosny, 1974) & + & + & + & + & + & - & - & - & - & - & - & + & - & - & + & - & - & - & - \\
\hline Oxycera rara (Scopoli, 1783) & - & - & - & - & - & - & - & - & - & - & - & - & - & - & + & - & - & - & - \\
\hline Thaumalea sp. & - & + & + & - & - & - & - & + & - & - & - & - & - & - & - & - & - & - & - \\
\hline Tipula sp. & + & - & + & - & - & - & - & - & - & - & - & - & - & + & - & - & - & - & - \\
\hline Number of Species & \begin{tabular}{|l|}
14 \\
\end{tabular} & 17 & 21 & 18 & 14 & 5 & 9 & \begin{tabular}{|l|}
12 \\
\end{tabular} & 14 & 16 & 15 & 10 & 20 & 20 & 24 & 4 & 17 & 10 & 14 \\
\hline
\end{tabular}


Alp Buffalora were scattered all over the ordination (Figure 3). The limnocrene LIM and the highest spring BUF3 differed the most. The ANOSIM confirmed overall significant differences between the sampling areas $(R=0.352, p=0.001)$. The differences between the springs in the Val Chavagl and around God dal Fuorn were greatest $(\mathrm{R}=0.744, \mathrm{p}=0.018)$, whereas the springs of the Alp Buffalora were not significantly separate from the springs in the other sampling areas. A grouping of the springs according to their electrical conductivity and their oxygen content revealed a significant separation $(\mathrm{R}=0.423, \mathrm{p}=0.003$ and $\mathrm{R}=0.328$, $\mathrm{p}=0.006$, respectively). The BEST analysis also revealed that the electrical conductivity and the oxygen content influenced the composition of the macrozoobenthic assemblages most $(\varrho=0.390)$, although the correlation is not high. Other abiotic factors did not have a significant influence on the composition of the macrozoobenthic assemblages in the springs. The location of the springs in a particular valley is most important.

\section{Discussion}

Electrical conductivity and oxygen saturation were identified as the main environmental factors differentiating the springs and their macrozoobenthic assemblages. The springs at the Alp Buffalora had the lowest electrical conductivity. This is most likely due to their location above the tree line with a naturally shorter retention time of the groundwater in the aquifer (Cantonati et al. 2006). Overall we consider the differences of the abiotic parameters between the springs as moderate. The study area provides similar environmental conditions for the macroinvertebrates as all springs are situated on the same geological layer. The altitudinal difference between the lowest and highest spring was less than $500 \mathrm{~m}$, an altitudinal gradient of the macroinvertebrate assemblages was therefore not evident. However, all springs in the area of the Alp Buffalora outside of the SNP are above the tree line, thus minimizing the input of leaf-litter as an important food-source. Even springs above the tree line seem to be heterotrophic systems with simple food webs and mostly omnivore invertebrates (Robinson et al. 2008). The limnocrene spring LIM, which was also investigated by Nadig (1942), differs morphologically from the other springs due to its large size $\left(62 \mathrm{~m}^{2}\right)$ and the depth of the pond $(2.1 \mathrm{~m})$. The very high electrical conductivity, which was also reported by Döring (2002) and Nadig (1942), is caused by a high sulphate concentration (Döring 2002). The extremely low oxygen concentrations emphasize the special and even hostile character of this spring.

Comparisons with the Red List of molluscs (Rüetschi et al. 2012) and of the Ephemeroptera, Plecoptera and Trichoptera (Lubini et al. 2012) showed that the SNP is an important nature protection zone. The two endangered mollusc species found are both associated with wet conditions occurring on wet

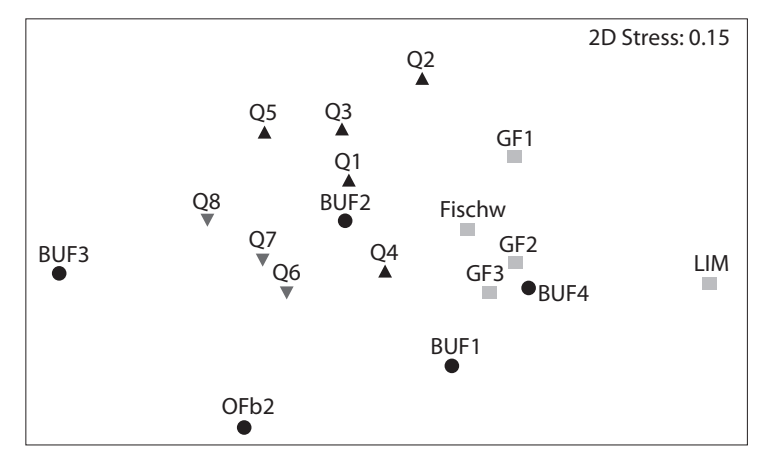

Figure 3 - Non-metric multidimensional scaling (nMDS) of the investigated springs based on the average of the quantitative faunistic sampling; similarity index: Bray-Curtis, transformation: fourth root; factor: area; $\boldsymbol{\nabla}=$ Val Chavagl; $\mathbf{\square}=$ God dal Fuorn; $\mathbf{\Delta}=$ Val Ftur; $\bullet=$ Buffalora; Analysis of Similarities (ANOSIM) with area as discriminating factor: $\mathrm{R}=0.352, p=0.001$.

meadows and also next to intact natural spring habitats (Boschi 2011), which still exist in the SNP. Quickella arenaria is vulnerable because of its fragmented habitat in the Alps. With climate change, this species might be replaced by more common species such as Succinella oblonga (Turner et al. 1998). Vertigo genesii has its main distribution in the canton Grisons. V. genesii is an endemic species for Switzerland (Turner et al. 1998) and highly endangered (Boschi 2011). According to Waringer \& Graf (2011), Drusus melanchaetes and Drusus nigrescens are endemic Trichoptera for the Western Alps, with $D$. melanchaetes restricted to an altitudinal distribution between $1960 \mathrm{~m}$ and $2560 \mathrm{~m}$ (Malicky 2004). In the SNP they probably reach the eastern border of their distribution area, they do not, for example, occur in Gesäuse National Park (Gerecke 2012). The species of the Drusinae are generally often restricted to small distribution areas and are typical cold-stenothermic species, which only occur in water bodies of high water quality and constant low water temperatures. They are therefore valuable bioindicators (Graf et al. 2002; Waringer \& Graf 2011). Overall, six different species of the genus Drusus were found in this study, most of them in the small Val Ftur. Many spring specialists are found among the Trichoptera listed as vulnerable (Lubini et al. 2012). The four vulnerable Trichoptera found in this study are still common in Switzerland. Their habitat, Alpine springs, is however severely endangered (Lubini et al. 2012). The highly endangered Plecoptera Nemoura undulata is an endemic species of the Central Alps above $1800 \mathrm{~m}$ and was only detected in Switzerland on the Furkapass and in the SNP (Lubini et al. 2012). Two specimens of $N$. undulata were also found in Berchtesgaden National Park in Germany (Gerecke \& Franz 2006) but not in Gesäuse National Park in the eastern part of Austria (Gerecke et al. 2012). In this study N. undulata was only found in the spring BUF3 outside the SNP on the Alp Buffalora. This spring is situated above the tree line and is composed of few inorganic substrates. Investigating 
more springs above the tree line within the SNP and Val Müstair BR would therefore be most desirable.

On the one hand, similar species assemblages were detected in the investigated springs due to similar environmental prerequisites. On the other hand, we found large small-scale differences between the species assemblages of the springs as one third of the taxa only occurred in one single spring. Many of the endangered or vulnerable species in particular only occurred in one spring. This underlines the high degree of individuality of the spring fauna (Bonettini \& Cantonati 1996; Weigand 1998; Lencioni et al. 2011). Moreover, the study revealed a grouping of the springs according to the valley or area they are situated in. This higher similarity of the macroinvertebrate assemblages of neighbouring springs points to the restricted dispersal abilities of spring species. This is especially true of the Drusinae, which almost exclusively occurred in the Val Ftur. It is therefore likely for species to become extinct if springs get damaged or polluted.

The springs at Alp Buffalora in Val Müstair BR outside of the SNP are not as strictly protected as the springs within the park borders. They are at least potentially threatened by anthropogenic impacts. Steiner (2005) mentioned fencing in BUF3 to prevent cattle entering the springhead. This was not evident in 2012. Despite the anthropogenic impact and despite their higher location, the spring fauna did not significantly differ from the spring fauna within the SNP. The species richness was similar to the species richness within the park and endangered or at least vulnerable Plecoptera species occurred as well. However, Drusinae were completely absent. Expanding the area of the SNP would be helpful in order to protect sensitive habitats such as springs. In a first step, fencing springs can be helpful to prevent damages to the springs and their surroundings. Monitoring of the springs in the SNP is being continued in 2013. However, a comprehensive monitoring campaign, such as the ones undertaken in Berchtesgaden and Gesäuse National Parks would be desirable to understand similarities and differences between protected areas. Moreover, long-term studies are necessary to understand the consequences of global climate change on spring ecosystems and for the protection of springs (Gerecke et al. 2011). The study stresses the importance of protected areas as sanctuaries for endangered species living in unique habitats such as springs.

\section{Conclusion}

In the high-altitude springs in the SNP and also in Val Müstair BR, macrozoobentic assemblages of a high degree of individuality were found despite similar environmental prerequisites. Rare and endemic species occur in low abundances and at isolated patches. They are in danger of extinction if springs get disturbed. Considering global climate change and anthropogenic impacts, the SNP provides a valuable sanctuary for the cold-stenothermal fauna in Alpine springs. Moreover, protection of the springs outside of the park, especially in Val Müstair BR, would be desirable as they are also inhabited by endangered species. A comprehensive monitoring of the springs in this area would help to further assess the value of the SNP as a sanctuary for endangered and endemic spring species.

\section{Acknowledgements}

We thank the SNP for supporting the project financially and logistically. We acknowledge numerous people who helped with the fieldwork. We thank Dr. Verena Lubini for verifying the EPT taxa, Michael Geiser for verifying the Coleoptera and Florin Rutschmann for verifying the Gastropoda. We also thank Lara Schmidlin, who improved the English and an anonymous reviewer who made valuable comments on the manuscript.

\section{References}

Aubert, J. 1965. Les Plécoptères du Parc National Suisse. Ergebnisse der wissenschaftlichen Untersuchungen im Schweizerischen Nationalpark 10. Aarau.

Bonettini, A.M. \& M. Cantonati 1996. Macroinvertebrate assemblages of springs of the River Sarca catchment (Adamello-Brenta Regional Park, Trentino, Italy). Crunoecia 5: 71-78.

Bader, C. 1975. Die Wassermilben des Schweizerischen Nationalparks. Ergebnisse der wissenschaftlichen Untersuchungen im Schweizerischen Nationalpark 14. Aarau.

Boschi, C. 2011. Die Schneckenfauna der Schweiz. Bern, Stuttgart, Wien.

Cantonati, M. \& K. Ortler 1998. Using spring biota of pristine mountain areas for long term monitoring. Hydrology, Water Resources and Ecology in Headwaters (Proceedings of the Headwater'98 Conference held at Merano / Meran, Italy, April 1998). LAHS Publication 248: 379-385.

Cantonati, M., R. Gerecke \& E. Bertuzzi 2006. Springs of the Alps - sensitive ecosystems to environmental change: from biodiversity assessments to longterm studies. Hydrobiologia 562: 59-96.

Cantonati, M., L. Füreder, R. Gerecke, I. Jüttner \& E.J. Cox 2012. Crenic habitats, hotspots for freshwater biodiversity conservation: toward an understanding of their ecology. Freshwater Science 31: 463-480.

Clarke, K.R. \& R.N. Gorley 2006. Primer v6. PRIMER-E. Plymouth.

Döring, M. 2002. Ecological assessment of springs and spring brooks in the Swiss National Park: Combining Fieldwork with Geodesy (GPS / Tachymetry) and GIS. Diploma Thesis. EAWAG, Zürich.

Gerecke, R. \& H. Franz 2006. Quellen im Nationalpark Berchtesgaden. Lebensgemeinschaften als Indikatoren des Klimawandels. Forschungsbericht 51. Nationalparkverwaltung Berchtesgaden.

Gerecke, R., M. Cantonati, D. Spitale, E. Stur \& S. Wiedenbrug 2011. The challenges of long-term eco- 
logical research in springs in the northern and southern Alps: indicator groups, habitat diversity, and medium term change. Journal of Limnology 70 (Suppl. 1): 168-187.

Gerecke, R., H. Haseke, J. Klauber \& A. Maringer 2012. Quellen. Schriften des Nationalparks Gesäuse, Band 7, Weng im Gesäuse.

Graf, W., U. Grasser \& J. Waringer 2002. Trichoptera. In: Moog, O. (ed.), Fauna Aquatica Austriaca, Lieferung 2002. Bundesministerium für Land- und Forstwirtschaft, Wien.

Ketterer, C. \& R. Haller 2009. 200 Jabre Wetter, Witterung und Klima im Gebiet des Schweizer Nationalparks auf regionalen Klimasimulationen. Rückblick und Szenarien. Praktikumsarbeit Schweizer Nationalpark.

Lencioni, V., L. Marziali, B. Rossaro 2011. Diversity and distribution of chironomids (Diptera, Chironomidae) in Alpine and pre-Alpine springs (Northern Italy). Journal of Limnology 70 (Suppl.1): 106-121.

Lubini, V., S. Knispel, M. Satori, H. Vicentini \& A. Wagner 2012. Rote Listen Eintagsfliegen, Steinfliegen, Köcherfliegen. Gefährdete Arten der Schweiz, Stand 2010. Bundesamt für Umwelt, Bern, und Schweizer Zentrum für die Kartographie der Fauna, Neuenburg.

Malicky, H. 2004. Atlas of European Trichoptera. Dordrecht.

Meteo Schweiz 2013. Klimadiagramme und -normwerte an Stationen. Station Buffalora 1980-2010. Available at: www.meteoschweiz.admin.ch (accessed: 10/04/13)

Nadig, A. 1942. Hydrobiologische Untersuchungen in Quellen des Schweizerischen Nationalparks im Engadin. Ergebnisse der wissenschaftlichen Untersuchungen im Schweizerischen Nationalpark 1. Aarau.

Nold, H. \& H.J. Schmassmann 1955. Chemische Untersuchungen in der Ova da Val Ftur im Schweizerischen Nationalpark (Beitrag zur Kenntnis des Stoffhaushaltes der Hochgebirge). Ergebnisse der wissenschaftlichen Untersuchung im Schweizerischen Nationalpark 31. Liestal.

Oertli, B., N. Indermuehle, S. Angelibert, H. Hinden \& A. Stoll 2008. Macroinvertebrate assemblages in 25 high alpine ponds of the Swiss National Park (Cirque of Macun) and relation to environmental variables. Hydrobiologia 597: 29-41.

Robinson, C.T., D. Schmid, M. Svoboda \& S.M. Bernasconi 2008. Functional measures and food webs of high elevation springs in the Swiss alps. Aquatic Sciences 70: 432-445.

Rüetschi J., P. Stucki, P. Müller, H. Vicentini \& F. Claude 2012. Rote Liste Weichtiere (Schnecken und Muscheln). Gefährdete Arten der Schweiz, Stand 2010. Bundesamt für Umwelt, Bern, und Schweizer Zentrum für die Kartografie der Fauna, Neuenburg.

Steiner, B. 2005. Hydrogeologie und -geochemie von ausgewählten Quellen im Schweizerischen Nationalpark. Diplomarbeit, Universität Bern.

Trümpy, R., S.M. Schmid, P. Conti \& N. Froitzheim 1997. Erläuterungen zur Geologischen Karte 1:50000 des Schweizerischen Nationalparks. Geologische Spezialkarte Nr.
122. Nationalpark-Forschung in der Schweiz. Vol. 87. Zernez.

Turner, H., J.G.J. Kuiper, N. Thew, R. Bernasconi, J. Rüetschi, M. Wüthrich† \& M. Gosteli 1998. Mollusca. Atlas der Mollusken der Schweiz und Liechtensteins. Fauna Helvetica, Band 2. Centre Suisse de la cartographie de la faune.

Van der Kamp, R.O. 1995. The hydrogeology of springs in relation to the biodiversity of spring fauna: a review. In: Ferrington, L.C. (ed.), Special Publication Number 1: Biodiversity of aquatic insects and other invertebrates in springs. Journal of the Kansas Entomological Society 68: 4-17.

Von Fumetti, S., P. Nagel, N. Scheifhacken \& B. Baltes 2006. Factors governing macrozoobenthic assemblages in perennial springs in north-western Switzerland. Hydrobiologia 568: 467-475.

Waringer, J. \& W. Graf 2011. Atlas der mitteleuropäischen Köcherfliegenlarven.

Weber, M. 2004. Erfassung, Bewertung und strukturelle Typisierung naturnaber Quellen im Schweizer Alpenraum. Diplomarbeit. Fachhochschule Eberswalde, Eberswalde.

Weigand, E. 1998. Biodiversität in alpinen Karstquellsystemen (Nationalpark. Kalkalpen, Österreich). Deutsche Gesellschaft für Limnologie (DGL). Tagungsbericht 1998, 1: 149-213. Göttingen.

Weigand, E. \& W. Graf 2004. Hydrobiologische Erstcharakterisierung bedeutender Karstquellen der Sulzkaralm (Nationalpark Gesäuse). Pilotprojekt Sulzkaralm. Unpubl. report. Bericht des Nationalpark Gesäuse GmbH.

Wigger, F. \& S. von Fumetti 2013. Quellen und ihre Lebensgemeinschaften in den Berner Alpen. Mitteilungen der Naturforschenden Gesellschaft Bern NF 70: 117-131.

Zollhöfer, J.M. 1997. Quellen die unbekannten Biotope: erfassen, bewerten, schütz̨en. Bristol Schriftenreihe Volume 6. Zürich.

Zollhöfer, J.M., A. Brunke \& T. Gonser 2000. A typology of springs in Switzerland by integrating habitat variables and fauna. Archiv für Hydrobiologie Suppl. 121: 349-376.

\section{Authors}

Stefanie von Fumetti*

is an environmental scientist specializing in freshwater ecology. Her focus is on the ecology of springs, mainly in the Swiss Alps. She is a research fellow at the University of Basel.

Contact: stefanie.vonfumetti@unibas.ch

\section{Susanne Felder*}

has an MSc in Geosciences from the University of Basel. She specializes in macroinvertebrates and wrote her master thesis about springs in the SNP. She is currently working for the canton Berne as a freshwater ecologist. Contact: susanne.felder@stud.unibas.ch * Biogeography Research Group, Department of Environmental Sciences, University of Basel. 